Vol. 15 (2006): 138-151.

\title{
Ammonia volatilization, nitrogen in soil, and growth of barley after application of peat manure and pig slurry
}

Pasi K. Mattila

Department of Applied Chemistry and Microbiology, PO Box 27, FI-00014 University of Helsinki, Finland, e-mail: pasi.mattila@helsinki.fi

\begin{abstract}
Peat is added to manure, because its low $\mathrm{pH}$ and capacity to adsorb ammonia $\left(\mathrm{NH}_{3}\right)$ give it potential to reduce nitrogen $(\mathrm{N})$ loss. Peat manure was prepared by mixing pig slurry with moderately humified Sphagnum peat. Less than $1 \%$ of applied ammoniacal $\mathrm{N}$ was volatilized as $\mathrm{NH}_{3}$ from peat manure and pig slurry within $8 \mathrm{~h}$ of surface application on clay loam soil according to JTI method. Incorporated manures showed even smaller $\mathrm{N}$ loss. The low volatilization was due to the adsorption of manure ammoniacal $\mathrm{N}$ by peat, and the infiltration of slurry into harrowed, moist clay soil. In another experiment, peat manure was applied on polypropylene fabric without soil contact. Within the first 3 days there was only 9\% reduction in the ammoniacal $\mathrm{N}$ of peat manure, but the major part of it was lost during several weeks of dry and warm weather. Peat manure did not cause any major improvements on the growth and $\mathrm{N}$ uptake of spring barley in spring and early summer as compared with slurry. Moisture deficit limited the availability of ammoniacal $\mathrm{N}$ of manures. As compared with surface application, incorporation of manures increased nitrification of ammonium in the soil, and dry matter mass (19-73\%) and N uptake of barley. Supplementing manures with inorganic NPK fertilizer increased both dry matter mass (40-98\%) and N concentration of barley stand.
\end{abstract}

Key words: nitrogen, ammonia volatilization, animal manures, slurries, peat, barley

\section{Introduction}

Ammonia $\left(\mathrm{NH}_{3}\right)$ volatilization is a major pathway of nitrogen $(\mathrm{N})$ emissions to the air and of subsequent $\mathrm{N}$ deposition. Agriculture, particularly ani- mal manure, is the main source of $\mathrm{NH}_{3}$ emissions in Finland, like in other European countries. In Western Europe, $25 \%$ of the $\mathrm{N}$ excreted by farm animals is lost through $\mathrm{NH}_{3}$ emissions and $43 \%$ of the emissions occur after manure application in the field (ECETOC 1994). Simultaneously with the 
Vol. 15 (2006): 138-151.

decrease of sulphur deposition, needle analyses have been indicating high $\mathrm{N}$ concentrations in forests and increased $\mathrm{N}$ availability for trees near agricultural areas. These high $\mathrm{N}$ levels have adverse effects on forest ecosystems (Luyssaert et al. 2003). Ammonia is also an important factor in soil acidification (van Breemen et al. 1982). Controlling $\mathrm{NH}_{3}$ emissions is, thus, of great concern in manure management.

Peat has proven effective in suppressing $\mathrm{NH}_{3}$ volatilization when mixed with manure (Kemppainen 1987, Al-Kanani et al. 1992). The most suitable type of peat for manure treatment is moderately humified Sphagnum peat. It is acidic and has a high cation exchange capacity (Puustjärvi 1956), whereby it can adsorb $\mathrm{NH}_{3}$ as ammonium $\left(\mathrm{NH}_{4}^{+}\right)$in a plant-available form. In Kemppainen's (1987) laboratory experiment, the $\mathrm{NH}_{3}$ adsorption capacity of Sphagnum peat was $2.3 \%$ per dry matter (DM) mass of peat, whereas the capacity of straw was only $0.4-0.6 \%$. Sphagnum peat also has a high capacity to absorb water (Puustjärvi 1976). In Finland, a country with large peat resources, peat has been used traditionally as a bedding material for domestic animals on some farms. A new way to use peat is to mix it with animal slurry to enable the storing of manure in a solid form, when the storage capacity for slurry is insufficient (Mattila 2006).

The effectiveness of peat manure as $\mathrm{N}$ source for spring barley was investigated in a large field experiment (Mattila 2006). Differences in $\mathrm{NH}_{3}$ volatilization and in the behaviour of manure $\mathrm{N}$ in the soil were possible factors leading to the $5-15 \%$ higher grain yields obtained with peat manure compared with slurry. The purpose of the study reported here was to evaluate the ability of peat to 1 ) reduce $\mathrm{NH}_{3}$ volatilization from pig slurry in the field and to 2) improve the uptake of manure $\mathrm{N}$ by spring barley in spring and early summer. Ammonia volatilization was studied in two separate experiments, and the behaviour of manure $\mathrm{N}$ in the soil and $\mathrm{N}$ uptake by the crop were investigated in the large field experiment. Ammonia loss and recovery of $\mathrm{N}$ in the soil and barley stand were related to ammoniacal $\mathrm{N}$ of manures, because ammoniacal $\mathrm{N}$ is the fraction of manure $\mathrm{N}$ that is sus- ceptible to volatilization and forms the major source of manure $\mathrm{N}$ that is plant-available in the short-term (Salazar et al. 2005).

\section{Material and methods}

The experiments were carried out on a clay loam soil at MTT Agrifood Research Finland in Jokioinen $\left(60^{\circ} 49^{\prime} \mathrm{N}, 23^{\circ} 28^{\prime} \mathrm{E}\right)$. According to FAO classification the soil was a Vertic Cambisol (Alakukku and Elonen 1995). All the three experiments were located in the same area within a few hundred metres from each other.

\section{Measurement of $\mathrm{NH}_{3}$ volatilization}

$\mathrm{NH}_{3}$ volatilization was measured by equilibrium concentration technique (JTI method, Svensson 1994a). The method employs passive diffusional $\mathrm{NH}_{3}$ samplers of two structurally different types ( $\mathrm{C}$ and $\mathrm{L}$ ), which are placed at the soil surface both in ambient air and inside chambers that have a constant ventilation rate. Each chamber covers an area of $0.124 \mathrm{~m}^{2}$. One pair of $\mathrm{C}$ type samplers and one pair of $\mathrm{L}$ type samplers were exposed in each ambient air sampler holder, whereas one pair of $\mathrm{C}$ type samplers only were used in each chamber for each measurement period. The method gives the amount of volatilized $\mathrm{NH}_{3}$ per area and unit of time in the weather conditions prevailing in the ambient air during the measurement. While the $\mathrm{NH}_{3}$ volatilization rate in ambient air is affected by varying wind speed, $\mathrm{NH}_{3}$ concentration in the chambers is used as a measure of $\mathrm{NH}_{3}$ volatilization potential under constant air flow.

\section{Analysis of manures}

Concentrations of ammoniacal $\mathrm{N}\left(\mathrm{NH}_{3}-\mathrm{N}+\mathrm{NH}_{4}{ }^{+}-\mathrm{N}\right)$ and $\mathrm{DM}$ were determined in manure samples by the methods described by Kemppainen (1989, p. 176). For the analysis of ammoniacal N, $50 \mathrm{~g}$ of 
Mattila, P.K. Peat manure and slurry: $\mathrm{NH}_{3}$ loss, $\mathrm{N}$ in soil and barley

Table 1. Properties of the manures used in the $\mathrm{NH}_{3}$ volatilization experiments.

\begin{tabular}{llcccc}
\hline Experiment & Manure & $\begin{array}{c}\text { Application rate } \\
\mathrm{Mg} \mathrm{ha}^{-1}\end{array}$ & \multicolumn{2}{c}{$\begin{array}{c}\text { Ammoniacal N } \\
\mathrm{g} \mathrm{kg}^{-1}\end{array}$} & $\begin{array}{c}\text { Dry Matter } \\
\mathrm{kg} \mathrm{ha}^{-1}\end{array}$ \\
\hline Experiment 1 & Slurry & 22.9 & 4.1 & 95 & 6.0 \\
& Peat manure & 34.3 & 2.4 & 83 & 22.0 \\
Experiment 2 & Peat manure & 34.8 & 2.2 & 77 & 24.1 \\
\hline
\end{tabular}

a peat manure sample was extracted with $25 \mathrm{ml}$ $2 \mathrm{M} \mathrm{HCl}+25 \mathrm{ml} 2.5 \mathrm{M} \mathrm{CaCl}_{2}+150 \mathrm{ml}$ water, whereas $100 \mathrm{~g}$ of a slurry sample was extracted with $50 \mathrm{ml} 2 \mathrm{M} \mathrm{HCl}+50 \mathrm{ml} 2.5 \mathrm{M} \mathrm{CaCl}_{2}$. Concentration of $\mathrm{NH}_{4}{ }^{+}$in the extracts was determined by distilling $20 \mathrm{ml}$ of each extract with $\mathrm{MgO}$ with consequent titration of the distillate with $0.1 \mathrm{M}$ $\mathrm{HCl}$. Concentration of nitrate $\left(\mathrm{NO}_{3}^{-}\right)$was determined in selected samples by adding Devarda alloy after the distillation of $\mathrm{NH}_{4}^{+}$and then repeating the distillation. For the determination of DM concentration, manure samples were dried overnight at $70^{\circ} \mathrm{C}$.

\section{Ammonia volatilization experiment I}

Ammonia volatilization from pig slurry and peat manure applied to harrowed soil was measured by the JTI method in 1993. Surface applied manures were either incorporated by immediate harrowing with an s-tine harrow to ca. $5 \mathrm{~cm}$ depth or left on the soil surface. Pig slurry was obtained from a nearby commercial pig-fattening farm. The slurry was applied to the soil surface with a slurry spreader equipped with injection tines which in this study were fitted with splash plates and kept above the soil to simulate broadcast spreading. The spreader was weighed before and after applications to determine the rate of application of the slurry. Peat manure was made with a mixing machine (Lietu, manufactured by the Finnish company Vapo Oy, Mattila 2006) in the previous autumn by mixing pig slurry with moderately humified Sphagnum peat at the ratio of ca. 1:1.5 (v/v). Peat manure was weighed with a balance and spread manually with shovels. Two samples of 0.51 were taken from each manure during application for the analysis of ammoniacal $\mathrm{N}$ and DM concentration (Table 1). Peat manure samples consisted of several subsamples collected during application. Slurry flowing out of the spreader was sampled at the end of a pass over an experimental plot.

The experiment was arranged in a randomized complete block design with two replications. Plot size was $4 \mathrm{~m} \times 10 \mathrm{~m}$. Two chambers and two ambient air sampler holders were placed on each plot. Temperature and relative humidity of the air were measured with a psychrometer and wind speed with a cup anemometer (Table 2).

On the morning of 3 June manures were spread and incorporated. Ammonia measurement was started 40-60 min after spreading and continued for $4 \mathrm{~h}$. Rain prevented further measurement and suspended the experiment until the morning of 7 June, when manures were spread without incorporation and $\mathrm{NH}_{3}$ measurement was started 5-20 min later. After $4 \mathrm{~h}, \mathrm{NH}_{3}$ samplers were changed for another $4 \mathrm{~h}$ period. The chambers were not moved between the two sampling periods.

A supplementary measurement was carried out on 20 August to investigate the significance of the contact of manure with soil on $\mathrm{NH}_{3}$ volatilization from the manure. Pig slurry or peat manure was applied on bare soil or on a plastic film which pre-

Table 2. Average weather conditions in $\mathrm{NH}_{3}$ volatilization experiment 1 in 1993.

\begin{tabular}{lcrcc}
\hline Date & $\begin{array}{c}\text { Period } \\
\mathrm{h}\end{array}$ & $\begin{array}{c}\text { Temperature } \\
{ }^{\circ} \mathrm{C}\end{array}$ & $\begin{array}{c}\text { Relative } \\
\text { humidity } \%\end{array}$ & $\begin{array}{c}\text { Wind speed } \\
\mathrm{m} \mathrm{s}^{-1}\end{array}$ \\
\hline 3 June & $0-4$ & 9 & 87 & 3.9 \\
7 June & $0-4$ & 15 & 63 & 2.2 \\
7 June & $4-8$ & 15 & 58 & 4.1 \\
\hline
\end{tabular}


Vol. 15 (2006): 138-151.

vented the contact between manure and soil. Manures were applied only on the areas covered by JTI chambers, and $\mathrm{NH}_{3}$ concentration in the inside air of the chambers was measured as an indicator of $\mathrm{NH}_{3}$ volatilization potential. Before the application of manures the chamber sites were tilled by hand with a trowel. The experiment was carried out in two replications according to a complete block split-plot arrangement, where manure type was assigned to main plots and surface type to subplots. Eight chambers were used altogether. $312 \mathrm{~g}$ of slurry or $598 \mathrm{~g}$ of peat manure was applied under each chamber (area $0.124 \mathrm{~m}^{2}$ ) to obtain an application rate of $80 \mathrm{~kg} \mathrm{ha}^{-1}$ for ammoniacal $\mathrm{N}$, which was analysed from the manures before the experiment. The slurry was from the same farm and the peat manure from the same storage heap as in the measurement carried out in June. When applied on the plastic film, the slurry flowed to the lower parts of the film and covered only about one third of it. With each chamber, the measurement started immediately after the application of manure and lasted for $4 \mathrm{~h}$. During the measurement, the temperature of outside air was on average $15^{\circ} \mathrm{C}$ and relative humidity $78 \%$. Four soil samples were taken close to the chambers to measure the moisture content of surface soil ( $0-10 \mathrm{~cm}$ depth), which was on average $45 \%$ of dry weight. The moisture content was determined by measuring the weight loss of soil samples after drying at $105^{\circ} \mathrm{C}$ overnight.

\section{Ammonia volatilization experiment 2}

Ammonia volatilization in the field was calculated according to mass balance principle from determinations of ammoniacal $\mathrm{N}$ in peat manure exposed on thin polypropylene fabric, which is manufactured for the covering of horticultural crops. The fabric prevented the manure from mixing with soil and made it, thus, possible to obtain unsoiled manure samples. The experiment was carried out on harrowed soil in the summer of 1994. Temperature of the air was measured with a thermohygrograph and wind speed with a cup anemometer (Table 3 ).

Peat manure was made with Lietu machine six weeks before the start of the experiment by mixing pig slurry with moderately humified Sphagnum peat at the ratio of ca. 1:1.7 (v/v). Peat manure was spread manually with shovels on eight fabric sheets of $2 \mathrm{~m} \times 6 \mathrm{~m}$ (Table 1). As peat manure dried on the sheets, it adhered somewhat to the fabric, so that little was blown away by the wind during the experiment. The sheets were divided into four blocks, with two sheets in each. At each sampling time all the manure in one randomly selected $1 \mathrm{~m} \times 1 \mathrm{~m}$ square (DM weight ca. $800 \mathrm{~g}$ ) was collected from

Table 3. Average weather conditions between manure samplings in $\mathrm{NH}_{3}$ volatilization experiment 2 (7-17 June 1994). Precipitation after one period and before the next period is in parenthesis.

\begin{tabular}{rrrcl}
\hline Day & $\begin{array}{c}\text { Starting and } \\
\text { ending times }\end{array}$ & $\begin{array}{r}\text { Temperature } \\
{ }^{\circ} \mathrm{C}\end{array}$ & $\begin{array}{c}\text { Wind speed } \\
\mathrm{m} \mathrm{s}^{-1}\end{array}$ & $\begin{array}{c}\text { Precipitation } \\
\mathrm{mm}\end{array}$ \\
\hline 1 & $11: 30-21: 00$ & 19 & 4.9 & 0 \\
$1-2$ & $21: 00-08: 40$ & 9 & 3.0 & 0 \\
2 & $08: 40-21: 25$ & 19 & 5.8 & $2{ }^{1)}$ \\
$2-3$ & $21: 25-08: 35$ & 10 & 3.3 & 0 \\
3 & $08: 35-20: 35$ & 18 & 4.1 & $0(14)$ \\
5 & $09: 20-21: 20$ & 20 & 2.6 & 0 \\
$5-6$ & $21: 20-09: 20$ & 11 & 2.6 & 0 \\
7 & $08: 35-20: 35$ & 19 & 4.2 & 0 \\
8 & $08: 30-20: 30$ & 21 & 5.9 & 0 \\
11 & $08: 30-20: 30$ & 10 & 2.4 & 6 \\
\hline
\end{tabular}

1) $0.5 \mathrm{~h}$ of rain at the end of the period. 
Mattila, P.K. Peat manure and slurry: $\mathrm{NH}_{3}$ loss, $\mathrm{N}$ in soil and barley

each block. The $\mathrm{pH}$ of the peat manure samples was measured within 2 hours from sampling with a glass electrode $\mathrm{pH}$ meter from a suspension of 40 $\mathrm{ml}$ manure $+40 \mathrm{ml}$ water. In some cases manure was so dry that more water (total amount up to 80 $\mathrm{ml}$ ) had to be added to make the suspension fluid. Concentrations of DM, ammoniacal $\mathrm{N}$ and $\mathrm{NO}_{3}^{-}$ were measured later in samples stored at $-18^{\circ} \mathrm{C}$.

Simultaneously with the peat manure sampling experiment, $\mathrm{NH}_{3}$ volatilization was measured by the JTI method on three $10 \mathrm{~m} \times 10 \mathrm{~m}$ plots, where peat manure was applied on the soil surface at the same rate as on the fabric sheets. The concentration of $\mathrm{NH}_{3}$ both in chambers and in the ambient air was far below $1 \mathrm{ppm}\left(0.696 \mathrm{mg} \mathrm{m}^{-3}\right)$ under which the reliability of the technique was not investigated during the development of the method (Svensson 1994a). Therefore, the results were considered too unreliable to be presented.

\section{Nitrogen in soil and crop}

The behaviour of applied $\mathrm{N}$ in soil and the uptake of $\mathrm{N}$ by spring barley stand in spring and early summer were investigated in a large field experiment (main experiment) with spring barley conducted in 1990-1993. Pig slurry and peat manure (a mixture of pig slurry and peat, ca. 1:1.5 v/v) were incorporated or surface applied annually supplying ammoniacal N 54-106 $\mathrm{kg} \mathrm{ha}^{-1} \mathrm{a}^{-1}$ and total N 65$209 \mathrm{~kg} \mathrm{ha}^{-1} \mathrm{a}^{-1}$. The manures were either the sole source of added $\mathrm{N}$ or supplemented with an inorganic NPK (20-4-8) fertilizer at $\mathrm{N} 40 \mathrm{~kg} \mathrm{ha}^{-1}$. The NPK fertilizer contained $\mathrm{N}$ as $\mathrm{NH}_{4}{ }^{+}$and $\mathrm{NO}_{3}{ }^{-}$. The experiment included also plots fertilized solely with the NPK fertilizer. Varying moisture conditions were created by different irrigation treatments. 25-34 mm of water was applied in each of the irrigations, which were carried out 2-5 days and 2-4 weeks after sowing of barley. Crop and soil samples were taken from unirrigated plots and from plots that received both of the two irrigations. The experiment had four replications. The details of the experiment are reported by Mattila (2006). Weather data (Fig. 1) was obtained from a weather station located about $2 \mathrm{~km}$ from the experimental field.

Barley stand samples were taken in late June before ear emergence in the years 1990 and 1993. The stand was cut from an area of $25 \mathrm{~cm} \times 200 \mathrm{~cm}$ in unirrigated and twice-irrigated plots. Total $\mathrm{N}$ was determined in dried $\left(60^{\circ} \mathrm{C}, 3-4 \mathrm{~d}\right)$ and milled samples by Kjeldahl method.

Soil samples were taken in 1990 and 1993 from the same places as barley stand samples in plots that had not received supplementary fertilizer. In the NPK fertilizer treatment, $\mathrm{N}$ levels 0 and $80 \mathrm{~kg}$ $\mathrm{ha}^{-1}$ were sampled. One soil sample per plot was
Fig. 1. Monthly average temperature and precipitation at Jokioinen (FMI 1991 and 1994, Drebs et al. 2002).

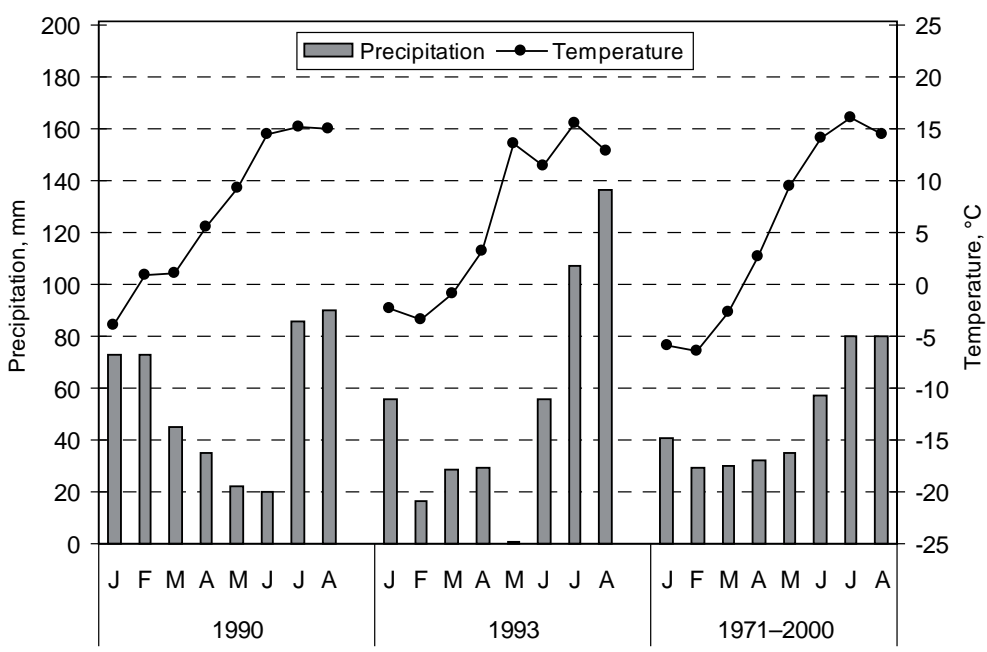


Vol. 15 (2006): 138-151.

taken with a special bucket from 0-10 cm depth from an area of $10 \mathrm{~cm} \times 100 \mathrm{~cm}$. In 1993, in two of the four blocks, samples were also taken from 10$20 \mathrm{~cm}$ depth. The soil was mixed in a tub and a subsample of ca. $0.5 \mathrm{~kg}$ was taken into a plastic bag. The samples were put into a cool box for transportation to storage. Concentration of inorganic soil $\mathrm{N}\left(\mathrm{NO}_{3}{ }^{-} \mathrm{N}+\mathrm{NH}_{4}{ }^{+}-\mathrm{N}\right)$ was determined by extraction with $2 \mathrm{M} \mathrm{KCl}$ and subsequent spectrophotometric measurement (Esala 1991, p. 253) from soil samples kept at $4{ }^{\circ} \mathrm{C}$ for a few weeks (1990) or stored for several months at $-18^{\circ} \mathrm{C}$ (1993). The apparent recovery of $\mathrm{N}$ was calculated by dividing the difference in barley stand $\mathrm{N}$ or inorganic soil $\mathrm{N}$ between fertilized and unfertilized plot by the amount of ammoniacal manure $\mathrm{N}$ and total inorganic fertilizer $\mathrm{N}$ applied to the fertilized plot.

\section{Statistical analysis}

The results of the $\mathrm{NH}_{3}$ volatilization experiments were analysed with repeated measures analysis of variance using the MIXED procedure of SAS statistical software version 6.08 (SAS Institute Inc. 1990 and 1992). Pairwise comparisons were carried out using contrasts (Steel and Torrie 1981). Analysis of variance was performed for crop stand $\mathrm{DM}$ mass and $\mathrm{N}$ concentration and soil $\mathrm{N}$ measured in slurry and peat manure plots according to split-plot design with the GLM procedure of SAS statistical software version 6.12 (SAS Institute Inc. 1990). Some treatments were arranged as strips, which was considered in determining the structure of the error terms (Steel and Torrie 1981, Mattila 2006). The effects of application method and supplementary fertilization were analysed separately for slurry and peat manure because the arrangement of these treatments was different in slurry and peat manure plots. Differences with $\mathrm{P}<0.05$ were considered significant.

\section{Results}

\section{Ammonia volatilization measured by JTI method}

Ammonia emission from incorporated manures was negligible and also surface applied manures showed low emission (Fig. 2). The comparison of incorporation and surface application is complicated by the difference in weather conditions. During the $8 \mathrm{~h}$ measurement the average volatilization of $\mathrm{NH}_{3}-\mathrm{N}$ from surface applied slurry was $0.5 \mathrm{~kg} \mathrm{ha}^{-1}$, or $0.5 \%$ of the applied ammoniacal $\mathrm{N}$. From the surface applied peat manure, $\mathrm{NH}_{3}-\mathrm{N}$ volatilization was $0.6 \mathrm{~kg} \mathrm{ha}^{-1}$, or $0.8 \%$ of ammoniacal

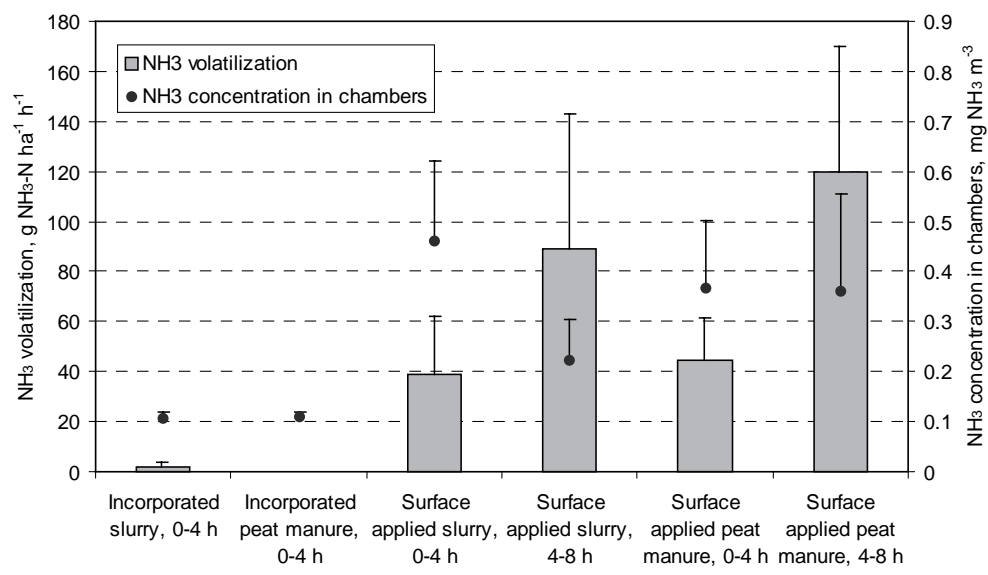

Fig. 2. Ammonia volatilization rate and $\mathrm{NH}_{3}$ concentration in chambers in $\mathrm{NH}_{3}$ volatilization experiment 1 . Incorporated manures were applied and measured on 3 June and surface applied ones on 7 June 1993. Narrow bars indicate standard error of mean. 
Mattila, P.K. Peat manure and slurry: $\mathrm{NH}_{3}$ loss, $\mathrm{N}$ in soil and barley

Table 4. Ammonia concentration $\left(\mathrm{mg} \mathrm{NH}_{3} \mathrm{~m}^{-3}\right)$ in JTIchambers over manure applied on tilled bare soil or on impermeable plastic film.

\begin{tabular}{lcc}
\hline & Bare soil & Plastic film \\
\hline Slurry & 0.10 & 5.88 \\
Peat manure & 0.28 & 0.22 \\
\hline
\end{tabular}

$\mathrm{N}$. The difference between slurry and peat manure was not statistically significant.

Ammonia volatilization from surface applied slurry and peat manure was significantly higher during the last $4 \mathrm{~h}$ than during the first period (Fig. 2). With surface applied slurry, $\mathrm{NH}_{3}$ concentration in chambers was higher during the first $4 \mathrm{~h}$ than during the next $4 \mathrm{~h}$, but with surface applied peat manure the difference was small.

In the supplementary measurement, the isolation of slurry from the soil with plastic film resulted in over 50 times higher $\mathrm{NH}_{3}$ concentration in chambers compared with application on tilled bare soil (Table 4), into which the slurry infiltrated readily. Peat manure was solid and did not infiltrate. Hence, the difference between peat manure applied on plastic film and on bare soil was small. The interaction of manure type and surface type was statistically significant.

\section{Changes in peat manure on fabric sheets}

The $\mathrm{pH}$ of the manure rose until the morning of Day 3, while the concentration of ammoniacal $\mathrm{N}$ diminished by about $9 \%$ within the first three days (Fig. 3). There was only $2 \mathrm{~mm}$ of rain at this time (Table 3) and, thus, leaching could not explain the loss of $\mathrm{N}$ from the manure.

There was $14 \mathrm{~mm}$ of precipitation between Days 3 and 5 (Table 3). Evidently the rain leached ammoniacal $\mathrm{N}$ from the manure into the soil, because by the morning of Day 5 the concentration of ammoniacal $\mathrm{N}$ decreased by $27 \%$ (Fig. 3). From this point on, ammoniacal $\mathrm{N}$ concentration, $\mathrm{pH}$ and $\mathrm{DM}$ concentration varied diurnally in the same way as on Day 3: $\mathrm{N}$ concentration and $\mathrm{pH}$ were higher and DM concentration lower in the morning than in the evening.
On Day 11, DM concentration was lower in the evening than in the morning, because there was $6 \mathrm{~mm}$ of precipitation during the day. The concentration of ammoniacal $\mathrm{N}$ did not change significantly.

By the evening of Day 11 the concentration of ammoniacal $\mathrm{N}$ in peat manure had decreased by $36 \%$. Thereafter the ammoniacal $\mathrm{N}$ concentration continued to fall during a long period of dry and warm weather. The last sample of peat manure was taken on 31 August (Day 86). At this time the concentration of ammoniacal $\mathrm{N}$ in peat manure $\mathrm{DM}$ was $1.64 \mathrm{~g} \mathrm{~kg}^{-1}$, which represented a total reduction of $82 \%$ in ammoniacal $\mathrm{N}$ during the experiment. As noted above, part of the reduction was probably due to rain, but most of it was likely the result of $\mathrm{NH}_{3}$ volatilization.

One possible sink for the ammoniacal $\mathrm{N}$ of peat manure was the conversion of $\mathrm{NH}_{4}^{+}$to $\mathrm{NO}_{3}{ }^{-}$by nitrification. To investigate this, the concentration of $\mathrm{NO}_{3}{ }^{-}$was analysed in peat manure samples taken at the start, in the evening of Day 3, in the morning of Day 5, and on Days 32, 60 and 86. $\mathrm{NO}_{3}{ }^{-}$was either absent or present in negligible amounts. Highest values were measured for Days 60 and 86, but even then the concentration of $\mathrm{NO}_{3}^{-}-\mathrm{N}$ was less than $10 \%$ of the concentration of ammoniacal N. Clearly, nitrification did not lower the concentration of ammoniacal $\mathrm{N}$ substantially. Because of the dry weather and the recalcitrance of peat to microbial decomposition (Persson and Kirchmann 1994) also, it is unlikely that immobilization or other microbial activity had a major effect on the concentration of ammoniacal $\mathrm{N}$ in the manure.

\section{Inorganic soil N}

The concentration of $\mathrm{NO}_{3}{ }^{-}$in surface soil $(0-10 \mathrm{~cm})$ was higher after incorporation than after surface application of manure, whereas the difference in the concentration of $\mathrm{NH}_{4}{ }^{+}$between the application methods was the reverse, except with slurry in 1990 (Fig. 4). Application method did not affect the total amount of inorganic soil $\mathrm{N}$ significantly because the effects on $\mathrm{NO}_{3}{ }^{-}$and $\mathrm{NH}_{4}{ }^{+}$compensated each other. Irrigation reduced the $\mathrm{NH}_{4}^{+}$concentra- 
Vol. 15 (2006): 138-151.
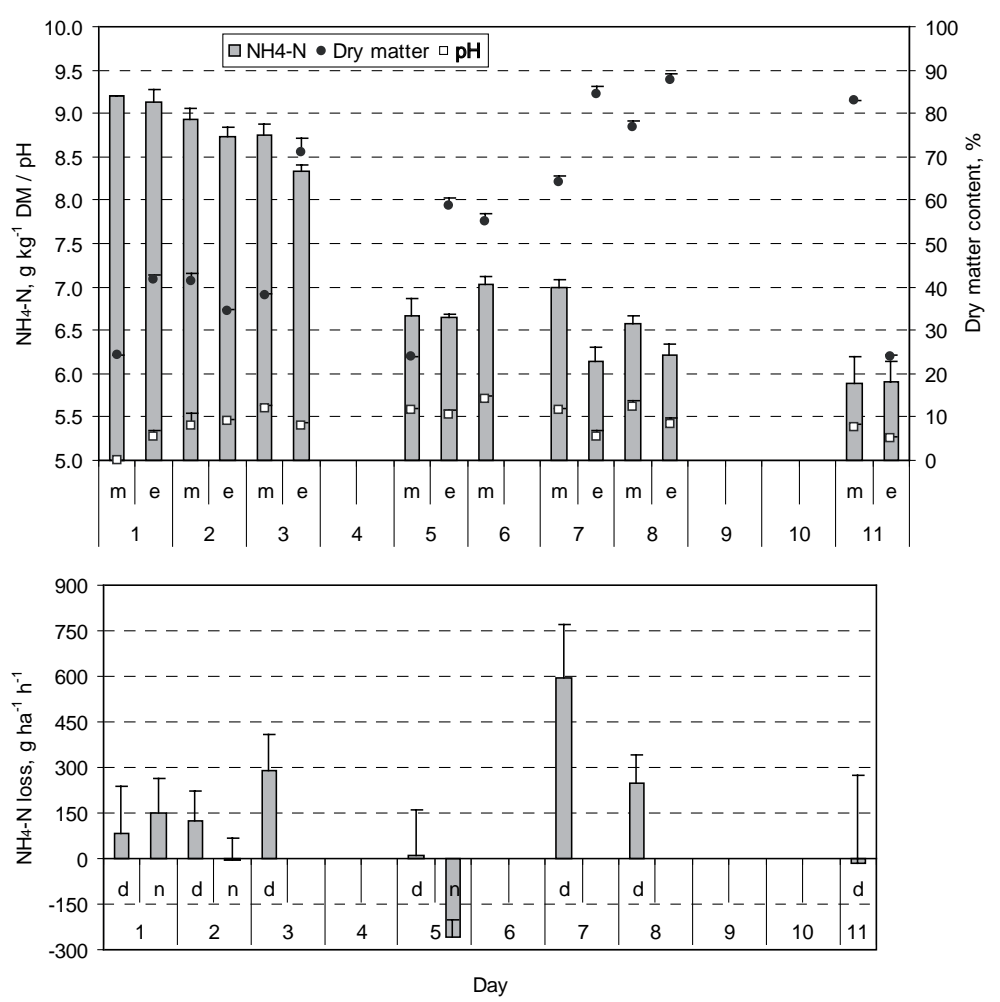

Fig. 3. Concentration of ammoniacal $\mathrm{N}$ and dry matter and $\mathrm{pH}$ in peat manure spread on polypropylene fabric (upper graph) and loss rate of ammoniacal $\mathrm{N}$ (lower graph). Peat manure was applied on Day 1. $\mathrm{m}=$ morning, $\mathrm{e}=$ evening, $\mathrm{d}=$ daytime, $\mathrm{n}=$ nighttime. Narrow bars indicate standard error of mean.

tion of surface soil in 1993 and elevated the concentration of $\mathrm{NO}_{3}^{-}$in 1990 (Fig. 4).

\section{Dry matter mass of barley stand}

In 1993, there was on average $14 \%$ more barley DM in peat manure plots than in slurry plots, but in 1990 the difference between the manures was not significant. Dry matter mass was higher with incorporation than with surface application: the difference was in peat manure plots 31 and $27 \%$ and in slurry plots 19 and $73 \%$ in 1990 and 1993, respectively. In 1990, supplementary fertilization increased DM mass significantly only with slurry (40\%), but in 1993 the increase was significant both with slurry (98\%) and with peat manure (84\%). In 1990 , irrigation almost doubled the DM mass of barley stand in manure amended plots, but with inorganic fertilizer irrigation increased DM mass only slightly. In 1993, when there was very little precipitation in May, manures applied without supplementary fertilization and irrigation produced clearly less barley DM than inorganic fertilizer.

\section{Nitrogen concentration of barley stand}

In 1993, incorporated slurry resulted in an $8 \%$ higher $\mathrm{N}$ concentration of barley stand than surface applied slurry. Both in 1990 and in 1993, inorganic fertilizer elevated the $\mathrm{N}$ concentration as supplement of the manures as well as when applied alone. Irrigation increased the $\mathrm{N}$ concentration in 1990.

\section{Apparent recovery of applied $\mathrm{N}$ in barley stand $\mathrm{N}$ and inorganic soil $\mathrm{N}$}

There were no significant effects on the recovery of $\mathrm{N}$ in inorganic soil $\mathrm{N}$, and in 1990 also the recovery 
Mattila, P.K. Peat manure and slurry: $\mathrm{NH}_{3}$ loss, $\mathrm{N}$ in soil and barley

1990, 0-10 cm depth

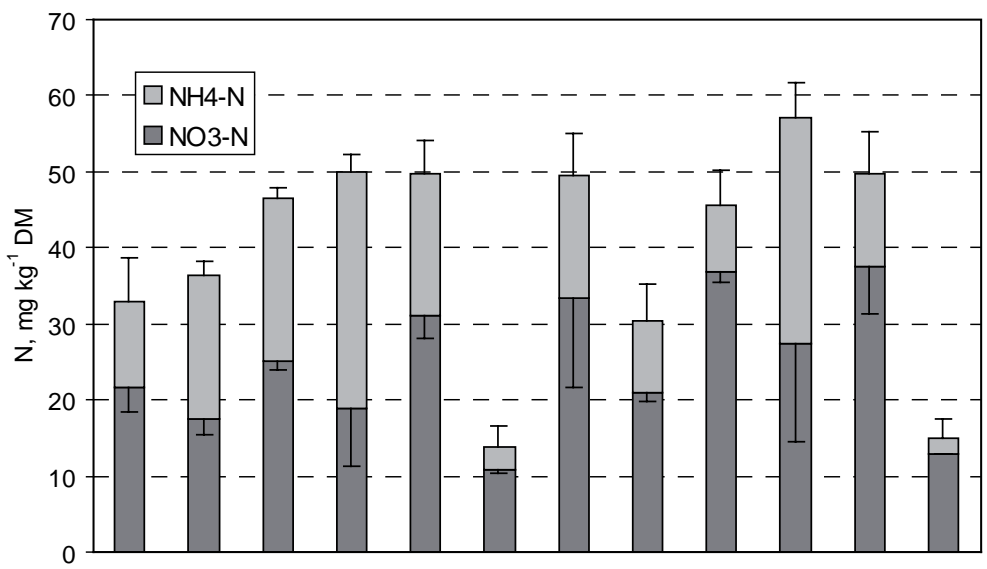

1993, 0-10 cm depth

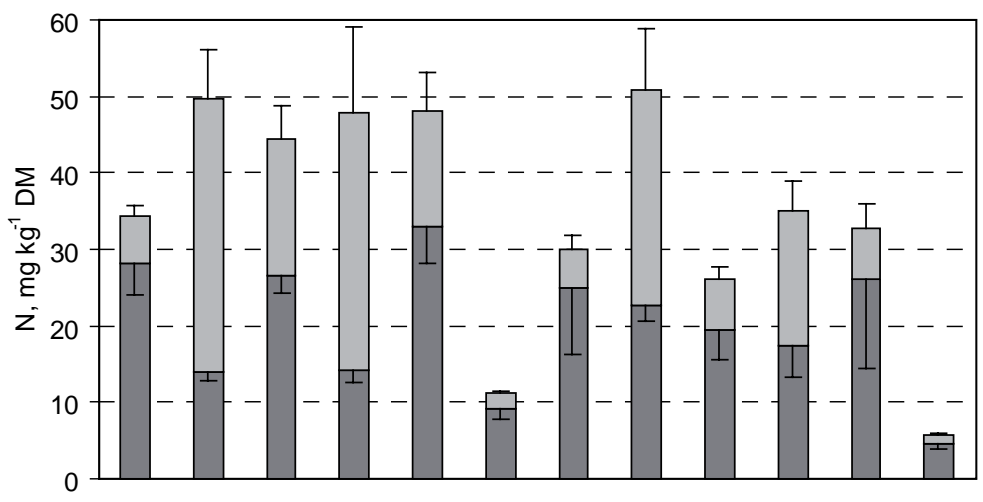

$1993,10-20 \mathrm{~cm}$ depth

Fig. 4. $\mathrm{NO}_{3}^{-}-\mathrm{N}$ and $\mathrm{NH}_{4}^{+}-\mathrm{N}$ contents of soil in late June or early July. INC = incorporated, SUR = surface applied, NPK = inorganic NPK fertilizer (N $80 \mathrm{~kg} \mathrm{ha}^{-1}$ ), Unf. $=$ unfertilized. Narrow bars indicate standard error of mean.

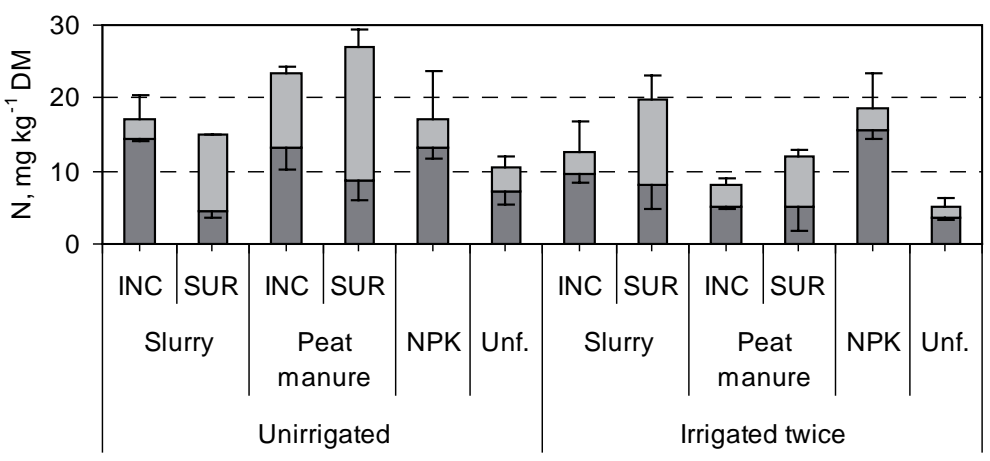

in barley stand $\mathrm{N}$ was not affected by the treatments significantly. In 1993, however, more N was recovered in barley stand with incorporated manures than with surface applied ones, and also irrigation added to the $\mathrm{N}$ recovery significantly (Fig. 5). Irrigation appeared to have a much weaker effect on $\mathrm{N}$ uptake with inorganic fertilizer than it did with the manures. 
Vol. 15 (2006): 138-151.

1990
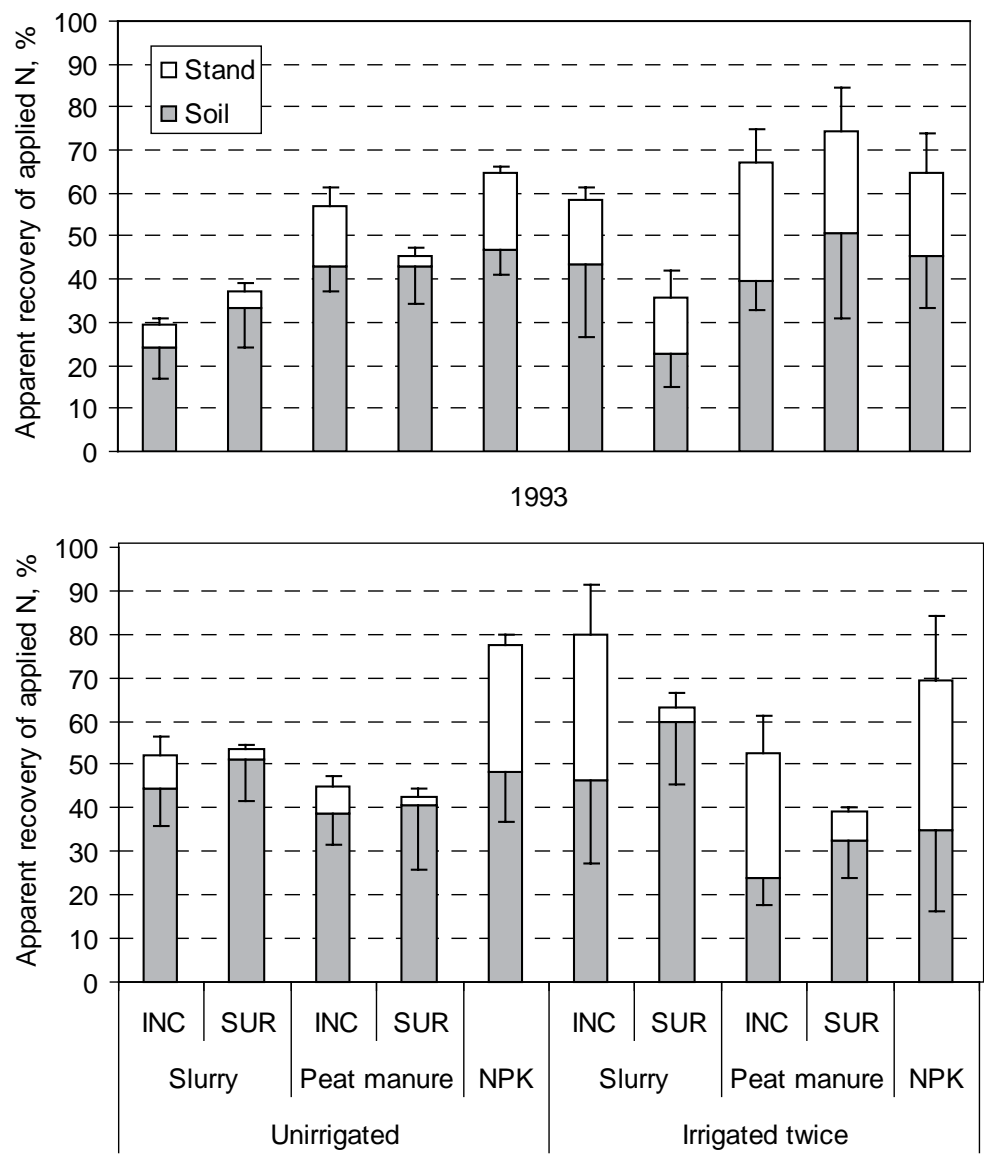

Fig. 5. Apparent recovery of ammoniacal $\mathrm{N}$ of manures and total $\mathrm{N}$ of inorganic fertilizer in barley stand $\mathrm{N}$ and soil inorganic $\mathrm{N}$ in late June or early July. INC = incorporated, SUR = surface applied, NPK = inorganic NPK fertilizer $\left(\mathrm{N} 80 \mathrm{~kg} \mathrm{ha}^{-1}\right)$. Narrow bars indicate standard error of mean.

\section{Discussion}

\section{Ammonia volatilization}

In Experiment 1, incorporation appeared to reduce $\mathrm{NH}_{3}$ volatilization, as also observed in several earlier experiments, when manure was well incorporated (Sommer and Christensen 1990, Svensson 1994b, Thompson and Meisinger 2002). Some volatilization was measured from surface applied manures, but it was remarkably low compared with other experiments (e.g. Beauchamp et al. 1982, Sommer and Ersbøll 1994, Smith et al. 2000, Thompson and Meisinger 2002, de Jonge et al. 2004). However, $\mathrm{NH}_{3}$ emission from broadcast cattle slurry measured by Svensson (1994b) was close to the low level reported here. Higher volatilization from surface applied manures during the last $4 \mathrm{~h}$ as compared with the first $4 \mathrm{~h}$ may have been due to higher wind speed during the latter period, because no corresponding difference was observed in the results of $\mathrm{NH}_{3}$ concentration in the chambers. Reduction of $\mathrm{NH}_{3}$ concentration in the chambers over slurry but not over peat manure indicates that the portion of ammoniacal $\mathrm{N}$ that was prone to rapid volatilization was emitted faster from slurry than from peat manure.

Infiltration of slurry into the recently tilled moist soil evidently limited $\mathrm{NH}_{3}$ loss in Experiment 1 . Harrowing the soil before slurry application promotes its infiltration, which reduces $\mathrm{NH}_{3}$ 
Mattila, P.K. Peat manure and slurry: $\mathrm{NH}_{3}$ loss, $\mathrm{N}$ in soil and barley

volatilization (Sommer and Ersbøll 1994, de Jonge et al. 2004). Furthermore, the physical nature of pig slurry allows its fast infiltration, when the structure of the soil is favourable (Misselbrook et al. 2005). Variation in the infiltration of slurry into the soil reflects to $\mathrm{NH}_{3}$ volatilization, too (Sommer et al. 2004). Physical properties of the surface on which slurry is applied have proven important for infiltration and $\mathrm{NH}_{3}$ volatilization. Consistently with the supplementary measurement of Experiment 1, Hoff et al. (1981) observed a several times higher emission from liquid swine manure applied on a plastic liner as compared with application on the soil surface, whereas Vandré and Clemens (1997) found only a small difference in a similar comparison where partial freezing of soil limited infiltration. Smith et al. (2000) measured higher $\mathrm{NH}_{3}$ volatilization from slurry applied on hard and dry grassland soil than from slurry applied on moist grassland or arable soil. Similarly, Mattila and Joki-Tokola (2003) measured a much higher $\mathrm{NH}_{3}$ emission from slurry applied to ley than in the experiments reported here. Thompson and Meisinger (2002) observed lower $\mathrm{NH}_{3}$ loss from manure incorporated into moist soil than into dry soil, but excessive moisture may increase $\mathrm{NH}_{3}$ volatilization (Sommer and Christensen 1990) if it prevents infiltration. When slurry is applied at a moderate rate to a soil with a high capacity to absorb it, differences between surface application and incorporation or injection may be small (Vandré and Kaupenjohann 1998).

Peat adsorbs $\mathrm{NH}_{3}$ and, thus, reduces $\mathrm{NH}_{3}$ volatilization, even though surface applied solid manure is prone to higher relative $\mathrm{NH}_{3}$ loss than slurry (Lauer et al. 1976, Svensson 1994b) because it does not infiltrate into the soil. However, during several weeks under dry and warm weather ammoniacal $\mathrm{N}$ is gradually lost also from peat manure. For the $\mathrm{N}$ of surface applied peat manure to move into the soil and become available for plants, plentiful rain or irrigation is needed. Incorporation of peat manure into the soil improves the availability of $\mathrm{N}$ and other nutrients for plants, but because $\mathrm{NH}_{3}$ volatilization is slow, rapid incorporation is not as important as after the application of slurry, when the time-lag between application and incor- poration may have a significant effect on the $\mathrm{NH}_{3}$ loss (Huijsmans and de Mol 1999).

As with surface applied peat manure in Experiment 2, Dendooven et al. (1998) observed a threeday rise in $\mathrm{pH}$ of a soil amended with pig slurry. The increase in $\mathrm{pH}$ was most likely caused by the volatilization of carbon dioxide from the manure (Sommer et al. 1991). This probably enhanced $\mathrm{NH}_{3}$ volatilization, which is the apparent reason for the reduction of ammoniacal $\mathrm{N}$. The reduction in ammoniacal $\mathrm{N}$ concentration was largest during the third day. The increase in DM concentration was likewise largest during this time, and the drying of the manure probably accelerated $\mathrm{NH}_{3}$ volatilization by increasing the concentration of ammoniacal $\mathrm{N}$ in the liquid phase of the manure (Lauer et al. 1976). The effect of drying on $\mathrm{NH}_{3}$ volatilization is not consistent, however, because drying may have a limiting effect, e.g. through surface crusting (Sommer et al. 1991, Thompson and Meisinger 2002). The $\mathrm{pH}$ of the manure decreased during the third day, perhaps due to $\mathrm{NH}_{3}$ volatilization. The volatilization of carbon dioxide had obviously ceased and it did not elevate the $\mathrm{pH}$ any more.

The diurnal cycle of ammoniacal $\mathrm{N}$ concentration, $\mathrm{pH}$ and DM concentration observed in Experiment 2 , evidently depended on the air humidity, which was higher at night and lower in the daytime. In daytime, water and probably also $\mathrm{NH}_{3}$ evaporated from the peat manure into the air. The reduction in the amount of ammoniacal $\mathrm{N}$ in peat manure would cause a fall in $\mathrm{pH}$. At night the reverse took place: peat absorbed water and $\mathrm{NH}_{3}$ from the air. In these conditions, the reduction of ammoniacal $\mathrm{N}$ in daytime does not represent actual net loss of ammoniacal N. Diurnal variation in $\mathrm{NH}_{3}$ volatilization has also been observed in earlier experiments (Beauchamp et al. 1982, Neftel et al. 1998).

\section{Nitrogen in soil and barley stand}

The ammoniacal $\mathrm{N}$ of manure incorporated into the soil is nitrified into $\mathrm{NO}_{3}{ }^{-}$or partially immobilized into soil microbial biomass within a few weeks (Jensen et al. 2000), if soil conditions favour microbial activity. Microbial immobilization 
Vol. 15 (2006): 138-151.

and fixation into clay minerals may reduce the amount of plant available ammoniacal $\mathrm{N}$ in the soil (Trehan and Wild 1993, Paul and Beauchamp 1994) and these processes are likely sinks for the manure ammoniacal $\mathrm{N}$, that was not included in the pools of inorganic soil $\mathrm{N}$ and crop stand $\mathrm{N}$ in the main experiment. Some $\mathrm{N}$ is bound in root biomass, too. A substantial part of both immobilized and fixed $\mathrm{N}$ may be released during the same growing period, but the availability of $\mathrm{N}$ is delayed. In some cases (e.g. Flowers and Arnold 1983), manure has not produced any significant increase in $\mathrm{N}$ mineralization after the immobilization phase.

In dry conditions, the $\mathrm{N}$ of surface applied manure remains mostly unavailable for both soil microbes and plants. This can be seen as lower $\mathrm{NO}_{3}{ }^{-}$ and higher $\mathrm{NH}_{4}^{+}$concentration in the soil after surface application than after incorporation of manure. The result is in agreement with observations of Sierra et al. (2001) for sewage sludge. With incorporated manures, the ratio of $\mathrm{NO}_{3}{ }^{-}$to $\mathrm{NH}_{4}{ }^{+}$was at the same level as in inorganic fertilizer plots. High concentration of $\mathrm{NH}_{4}{ }^{+}$in surface application plots indicates that $\mathrm{NH}_{3}$ volatilization has not been extensive, which is also shown by the results of $\mathrm{NH}_{3}$ volatilization measurements.

In 1993, when soil samples were taken from both $0-10 \mathrm{~cm}$ and $10-20 \mathrm{~cm}$ depth, the deeper soil layer contained clearly less $\mathrm{N}$ than did the surface layer. The leaching of $\mathrm{N}$ to $10-20 \mathrm{~cm}$ depth seems to have been small in both unirrigated and irrigated plots. Irrigation or rain can to some extent leach soluble $\mathrm{N}$ from surface-applied manure into the surface soil (Beauchamp et al. 1982, Cabrera and Vervoort 1998). Also, irrigation moistens the surface soil, which enhances nitrification (Sierra et al. 2001). Thus, irrigated soil contained more $\mathrm{NO}_{3}^{-}$ and less $\mathrm{NH}_{4}^{+}$than unirrigated soil. Increased moisture may also accelerate $\mathrm{N}$ immobilization (Flowers and Arnold 1983).

\section{Conclusions}

Peat retards $\mathrm{NH}_{3}$ volatilization from manure, but moisture is needed to enable a crop to utilize the ammoniacal $\mathrm{N}$ adsorbed by the peat. Incorporation is not needed as urgently to prevent $\mathrm{NH}_{3}$ loss from surface applied peat manure as from surface applied slurry. Ammonia volatilization may be small also from surface applied slurry, if the soil absorbs slurry efficiently. There is a need for more knowledge about the factors related to soil surface that influence $\mathrm{NH}_{3}$ volatilization from surface applied manure.

Peat manure did not show any major improvements on the growth and $\mathrm{N}$ uptake of barley in spring and early summer compared with slurry. Position of manure in the soil has a marked effect on the behaviour of manure $\mathrm{N}$ and its availability for the crop mainly through the dependence of moisture conditions on soil depth. In dry weather, surface applied manure remains drier than incorporated manure. This reduces the utilization of manure $\mathrm{N}$ by the crop and also by soil microbes, which results in less nitrification. For both peat manure and slurry, incorporation will improve the utilization of manure $\mathrm{N}$ and sufficient moisture is necessary to make the manure $\mathrm{N}$ available for the crop.

Acknowledgements. The author dedicates this article to the late Professor Paavo Elonen, who designed the large field experiment reported here and supervised its field work. Technical assistance of the staff of Soils and Environment unit of MTT Agrifood Research Finland is gratefully acknowledged. The study was financially supported by the Finnish Ministry of Agriculture and Forestry and Vapo Oy.

\section{References}

Alakukku, L. \& Elonen, P. 1995. Cumulative compaction of a clay loam soil by annual repeated field traffic in autumn. Agricultural Science in Finland 4: 445-461.

Al-Kanani, T., Akochi, E., MacKenzie, A.F., Alli, I. \& Barrington, S. 1992. Organic and inorganic amendments to reduce ammonia losses from liquid hog manure. Journal of Environmental Quality 21: 709-715.

Beauchamp, E.G., Kidd, G.E. \& Thurtell, G. 1982. Ammonia volatilization from liquid dairy cattle manure in the field. Canadian Journal of Soil Science 62: 11-19.

Cabrera, M.L. \& Vervoort, A.A. 1998. Effect of timing of simulated rain on ammonia volatilization from surface- 
Mattila, P.K. Peat manure and slurry: $\mathrm{NH}_{3}$ loss, $\mathrm{N}$ in soil and barley

applied broiler litter. Communications in Soil Science and Plant Analysis 29: 575-586.

de Jonge, L.W., Sommer, S.G., Jacobsen O.H. \& Djurhuus, J. 2004. Infiltration of slurry liquid and ammonia volatilization from pig and cattle slurry applied to harrowed and stubble soils. Soil Science 169: 729-736.

Dendooven, L., Bonhomme, E., Merckx, R. \& Vlassak, K. 1998. $\mathrm{N}$ dynamics and sources of $\mathrm{N}_{2} \mathrm{O}$ production following pig slurry application to a loamy soil. Biology and Fertility of Soils 26: 224-228.

Drebs, A., Nordlund, A., Karlsson, P., Helminen, J. \& Rissanen, P. 2002. Climatological statistics of Finland 19712000. Climatic statistics of Finland 2002:1. Helsinki: Finnish Meteorological Institute. 98 p.

ECETOC 1994. Ammonia emissions to air in Western Europe. European Centre for Ecotoxicology and Toxicology of Chemicals. Technical Report No. 62. 196 p.

Esala, M. 1991. Split application of nitrogen: Effects on the protein in spring wheat and fate of ${ }^{15} \mathrm{~N}$-labelled nitrogen in the soil-plant system. Annales Agriculturae Fenniae 30: 219-309.

Flowers, T.H. \& Arnold, P.W. 1983. Immobilization and mineralization of nitrogen in soils incubated with pig slurry or ammonium sulphate. Soil Biology and Biochemistry 15: 329-335.

FMI 1991 and 1994. Meteorological yearbook of Finland 1991 and 1994. Helsinki: Finnish Meteorological Institute.

Hoff, J.D., Nelson, D.W. \& Sutton, A.L. 1981. Ammonia volatilization from liquid swine manure applied to cropland. Journal of Environmental Quality 10: 90-95.

Huijsmans, J.F.M. \& de Mol, R.M. 1999. A model for ammonia volatilization after surface application and subsequent incorporation of manure on arable land. Journal of Agricultural Engineering Research 74: 73-82.

Jensen, L.S., Pedersen, I.S., Hansen, T.B. \& Nielsen, N.E. 2000. Turnover and fate of ${ }^{15} \mathrm{~N}$-labelled cattle slurry ammonium-N applied in the autumn to winter wheat. European Journal of Agronomy 12: 23-35.

Kemppainen, E. 1987. Ammonia binding capacity of peat, straw, sawdust and cutter shavings. Annales Agriculturae Fenniae 26: 89-94.

Kemppainen, E. 1989. Nutrient content and fertilizer value of livestock manure with special reference to cow manure. Annales Agriculturae Fenniae 28: 163-284.

Lauer, D.A., Bouldin, D.R. \& Klausner, S.D. 1976. Ammonia volatilization from dairy manure spread on the soil surface. Journal of Environmental Quality 5: 134-141.

Luyssaert, S., Raitio, H. \& Fürst, A. 2003. Elemental foliar composition indicates environmental changes. In: The condition of forests in Europe: 2003 executive report. Geneva and Brussels: United Nations Economic Commission for Europe and European Commission. p. 21.

Mattila, P.K. 2006. Spring barley yield and nitrogen recovery after application of peat manure and pig slurry. Agricultural and Food Science 15: 124-137 (this issue).

Mattila, P.K. \& Joki-Tokola, E. 2003. Effect of treatment and application technique of cattle slurry on its utilization by ley: I. Slurry properties and ammonia volatilization. $\mathrm{Nu}$ trient Cycling in Agroecosystems 65: 221-230.

Misselbrook, T.H., Scholefield, D. \& Parkinson, R. 2005. Using time domain reflectometry to characterize cattle and pig slurry infiltration into soil. Soil Use and Management 21: 167-172.

Neftel, A., Blatter, A., Gut, A., Högger, D., Meixner, F., Ammann, C. \& Nathaus, F. J. 1998. $\mathrm{NH}_{3}$ soil and soil surface gas measurements in a triticale wheat field. Atmospheric Environment 32: 499-505.

Paul, J.W. \& Beauchamp, E.G. 1994. Short-term nitrogen dynamics in soil amended with fresh and composted cattle manures. Canadian Journal of Soil Science 74 : 147-155.

Persson, J. \& Kirchmann, H. 1994. Carbon and nitrogen in arable soils as affected by supply of $\mathrm{N}$ fertilizers and organic manures. Agriculture, Ecosystems \& Environment 51: 249-255.

Puustjärvi, V. 1956. On the cation exchange capasity of peats and on the factors of influence upon its formation. Acta Agriculturae Scandinavica 6: 410-449.

Puustjärvi, V. 1976. Micro- and macrostructure of Sphagnum moss peat from the standpoint of its water economy. Peat and plant yearbook 1973-75: 5-10.

Salazar F.J., Chadwick, D., Pain, B.F., Hatch, D. \& Owen, E. 2005. Nitrogen budgets for three cropping systems fertilised with cattle manure. Bioresource Technology 96: 235-245.

SAS Institute Inc. 1990. SAS/STAT User's guide, Version 6, Fourth edition. Volume 2. Cary, North Carolina, SAS Institute Inc. $846 \mathrm{p}$.

SAS Institute Inc. 1992. SAS Technical Report P-229. Cary, North Carolina, SAS Institute Inc. p. 289-366.

Sierra, J., Fontaine, S. \& Desfontaines, L. 2001. Factors controlling $\mathrm{N}$ mineralization, nitrification, and nitrogen losses in an Oxisol amended with sewage sludge. Australian Journal of Soil Research 39: 519-534.

Smith, K.A., Jackson, D.R., Misselbrook, T.H., Pain, B.F. \& Johnson, R.A. 2000. Reduction of ammonia emission by slurry application techniques. Journal of Agricultural Engineering Research 77: 277-287.

Sommer, S.G. \& Christensen, B.T. 1990. Ammoniakfordampning fra fast husdyrgødning samt ubehandlet, afgasset og filteret gylle efter overfladeudbringning, nedfældning, nedharvning og vanding. Summary: Ammonia volatilization from solid manure and raw, fermented and separated slurry after surface application, injection, incorporation into the soil and irrigation. Tidsskrift for Planteavl 94: 407-417. (in Danish)

Sommer, S.G. \& Ersbøll, S.K. 1994. Soil tillage effects on ammonia emission from surface-applied or injected animal slurry. Journal of Evironmental Quality 23: 493-498.

Sommer, S. G., Hansen, M.N. \& Søgaard, H.T. 2004. Infiltration of slurry and ammonia volatilisation. Biosystems Engineering 88: 359-367.

Sommer, S.G., Olesen, J.E. \& Christensen, B.T. 1991. Effects of temperature, wind speed and air humidity on ammonia volatilization from surface applied cattle slurry. Journal of Agricultural Science, Cambridge 117: 91-100.

Steel, R.G.D. \& Torrie, J.H. 1981. Principles and procedures of statistics. 2nd ed. Singapore: McGraw-Hill. 633 p.

Svensson, L. 1994a. A new dynamic chamber technique for measuring ammonia emissions from land-spread manure and fertilizers. Acta Agriculturae Scandinavica, Section B, Soil and Plant Science 44: 35-46. 
Vol. 15 (2006): 138-151.

Svensson, L. 1994b. Ammonia volatilization following application of livestock manure to arable land. Journal of Agricultural Engineering Research 58: 241-260.

Thompson, R.B. \& Meisinger, J.J. 2002. Management factors affecting ammonia volatilization from land-applied cattle slurry in the mid-Atlantic USA. Journal of Environmental Quality 31: 1329-1338.

Trehan, S.P. \& Wild, A. 1993. Effects of an organic manure on the transformations of ammonium nitrogen in planted and unplanted soil. Plant and Soil 151: 287-294.

van Breemen, N., Burrough, P.A., Velthorst, E.J., van Dobben, F.F., de Wit, T., Ridder, T.B. \& Reijnders, H.F. 1982.
Soil acidification from atmospheric ammonium sulphate in forest canopy throughfall. Nature 299: 548550 .

Vandré, R. \& Clemens, J. 1997. Studies on the relationship between slurry $\mathrm{pH}$, volatilization processes and the influence of acidifying additives. Nutrient Cycling in Agroecosystems 47: 157-165.

Vandré, R. \& Kaupenjohann, M. 1998. In situ measurement of ammonia emission from organic fertilizers in plot experiments. Soil Science Society of America Journal 62: 467-473.

\title{
SELOSTUS
}

\section{Turvelisäyksen vaikutus sian lietelannan ammoniakkitappioihin ja typen hyväksikäyttöön}

\author{
Pasi K. Mattila \\ Helsingin yliopisto
}

Karjanlanta tulisi levittää niin, että sen typpi tulee viljelykasvien käyttöön eikä kulkeudu ympäristöön. Ympäristönsuojelun ja viljelykasvien typensaannin kannalta on tärkeää pitää typen haihtuminen ammoniakkina lannan levityksen yhteydessä mahdollisimman pienenä. Lietelannan imeyttäminen turpeeseen vähentää ammoniakin haihtumisen riskiä, koska vähän maatunut rahkaturve sitoo ammoniakkia tehokkaasti. Tämän tutkimuksen tavoitteena oli selvittää, miten turvelisäys vaikuttaa ammoniakin haihtumiseen pellolle levitetystä sian lietelannasta ja lannan typen hyväksikäyttöön ohran lannoituksessa.

Äestetylle hiuesavimaalle levitettiin sian lietelantaa sellaisenaan tai turpeeseen imeytettynä. Alle $1 \%$ lantojen liukoisesta typestä haihtui ammoniakkina kahdeksan tunnin kuluessa levityksestä pellon pinnalle, ja äestämällä mullatuista lannoista haihtuminen oli vielä vähäisempää. Lietelannan tehokas imeytyminen äestettyyn, kosteaan maahan piti ammoniakin haihtumisen pienenä, kun taas turpeen ammoniakinsitomiskyky vähensi haihtumista kiinteästä turvelannasta, joka ei imeytynyt maahan. Toisessa kokeessa liukoisen typen väheneminen maan pinnalle harson päälle levitetystä turvelannasta oli hidasta, mutta merkittävä osa siitä poistui useita viikkoja kestäneen kuivan ja lämpimän sääjakson aikana. Kokeen toisen ja kahdeksannen päivän välillä turvelannan ammoniumpitoisuus, kosteus ja pH laskivat päivisin ja nousivat öisin.

Turvelisäys ei edistänyt merkittävästi lannan typen hyväksikäyttöä ja ohran kasvua alkukesällä. Kuivuus heikensi sekä lietelannan että turvelannan typen lannoitusvaikutusta. Lantojen multaaminen lisäsi lannan ammoniumtypen nitrifikaatiota ja ohran typenottoa pintalevitykseen verrattuna.

Koska ammoniakin haihtuminen turvelannasta on hidasta, multaaminen levityksen jälkeen ei ole yhtä kiireellistä kuin lietelannan, josta haihtuminen voi tosin myös olla vähäistä lannan imeytyessä maahan tehokkaasti. Multaaminen edistää sekä lietelannan että turvelannan typen hyväksikäyttöä ohran typenlähteenä. Vaikka ammoniakkitappiot jäisivätkin pieniksi, pintamaahan levitetyn lannan typpilannoitusvaikutus voi jäädä heikoksi kuivuuden vuoksi. 